\title{
LI. On a method of determining the amount of proteine compounds in vegetable substances
}

\section{J. Alfred Wanklyn \& W.J. Cooper}

To cite this article: J. Alfred Wanklyn \& W.J. Cooper (1877) LI. On a method of determining the amount of proteine compounds in vegetable substances, Philosophical Magazine Series 5 , 3:19, 382-385, DOI: 10.1080/14786447708639253

To link to this article: http://dx.doi.org/10.1080/14786447708639253

曲 Published online: 27 Jul 2009.

Submit your article to this journal $₫$

Џll Article views: 2

Q View related articles $₫$ 


\section{Messrs. Wanklyn and Cooper on the Determination}

the flame-temperature, and would therefore take place on all sides of the rod.

(3) A strongly heated surface also becomes covered with a deposit of soot. This would not be possible if the deposit were the result of the cooling action of the surface upon the flame.

(4) The carbon particles present in the luminous flame become visible when the flame is caused to rush against another flame or against a heated surface. The separated particles are rolled together into larger masses, so that the luminous mantle becomes filled with numerous glowing points. The soot of such a flame is very coarse-grained.

(5) The luminous mantle of a flame is not altogether transparent: the thicker the flame-layer and the greater the number of solid particles contained therein, the less transparent does it become. The transparency of a luminous flame is no greater than that of the (approirimately) equally thick stratum of soot which rises from the flame of burning turpentine, and which is universally allowed to contain many solid carbon particles. The luminous flame of hydrogen, containing solid chromic oxide, is as transparent as the hydrocarbonflame.

(6) Those fames which undoubtedly oue their luminosity to the presence of finely divided solid matter, produce characteristic shadows when viewed in sunlight. The only luminous flames which do not produce true shadows are those which consist of glowing vapours and gases. Luminous hydrocarbonflames produce strongly marked shadows in sunlight; these flames therefore contain finely divided solid matter. That this solid matter can be nothing but carbon is evident from the fact that other substances, capable of remaining solid at the temperature of these flames, are absent.

These proofs are, I think, sufficient to convince every one that the luminous flames of hydrocarbons actually contain solid carbon particles.

Darmstadt, Chemisches Laboratorium des Polytechnicums.

LI. On a Method of determining the Amount of Proteine Compounds in Vegetable Sulstances. By J. ALFRED WankLYN, Corresponding Member of the Royal Bavarian Academy of Sciences, and W. J. COOPER*

THE physiological doctrine that the animal does not produce proteine compounds, but simply transforms those proteine substances which it has taken in as food, lends great

\footnotetext{
* Communicated by the Authors.
} 
of Proteine Componuls in Feytuble Sustences. $\quad 3 \times 3$

importance to the determination of the amount of protrince compounds in different kinds of regetable food; and such a determination becomes of the utmost importance both to the physiologist and from a practical point of view.

Hitherto, however, this desideratum has been rery imperfectly supplied, and the chemist has very inarlequately answered the question as to the proteine value of the different vegetable foods. Gluten, legumen, regetable caseine, regetils lo albumen, as the various proteine substances occurring in vegutables have been called, vary much in properties. Some ot them are soluble and others are insoluble in water; and some are soluble in alcohol; and it would be difficult to draw up any general method of extracting the proteine compounds from vegetables so as to be enabled to weigh the proteine compound in a state of purity. Resort bas therefore been had to elementary analysis; and chemists have deduced the amount of proteine compounds from the percentage of nitrogen found on submitting the food to ultimate analysis.

To this procedure there are several objections which have, apparently, not been sufficiently insisted upon. Taking the case of wheaten flour (which is much more farourable than many other cases), the percentage of nitrogen is a little short of 2.00; yet neither the Will-and-Varrentrapp process nor the Dumas process of nitrogen-determination, as it is generally carried out, is at all adequate to the valuation of the proteine substance in flour.

The Will-and-Varrentrapp process, as those who have a critical knowledge of it are aware, is subject to special failure when it is applied to proteine substances, and is not a determination of nitrogen in these instances.

The Dumas method, as usually practised, is uncertain when it is applied to determine a minute quantity of nitrogenous substance in presence of a large quantity of non-nitrogenous organic matter. Possibly, if carried out with extraordinary care and extraordinary precautions, the Dumas process might become available for the purpose in view; but those persons who have practical knowledge of the difficulties besetting thin particular case will admit that extraordinary care would indeed be required, and that the process would be too impracticable for general employment.

The method by which we seek to accomplish the task before us is, we believe, especially adapted for this description of work.

We propose to measure the amount of proteine substances in regetables by the amount of ammonia which the regetalles gencrate when they are suljected to the action of a boiling solution of potash and permanganate of potash; in fiact, we 


\section{Messis. Wanklyn and Cooper on the Determination}

have made a special adaptation of the well-known ammonia process of water-analysis to the case of vegetable proteine.

The working details of our process are as follows :-

Into a litre flask a carefully weighed gramme of the vegetable substance to be analyzed is placed, and 20 cub. centims. of decinormal solution of caustic potash is added, and then water is added until the litre-mark is reached by the level of the liquid. The contents of the flask are then shaken up so as to ensure thorough mixture. In this manner we obtain a liquid of such a strength that each cubic centim. contains 1 milligramme of the flour or other vegetable substance to be operated upon. 10 or 20 cub. centims. of this liquid (i. e. 10 or 20 milligrammes of the vegetable substance) are convenient quantities to work with.

The next step is to get the retort in order as for a wateranalysis, and to place in it 300 or $500 \mathrm{cub}$. centims. of good drinking-water, and to add $50 \mathrm{cub}$. centims. of a solution containing $10 \mathrm{grms}$. of potash and $0.4 \mathrm{grm}$. of permanganate of potash (such as is used in water-analysis), and to distil until the residne in the retort no longer yields the slightest trace of ammonia. That having been done, 10 or 20 cub. centims. of the liquid containing the vegetable substance are to be added and the distillation proceeded with. The vegetable substance will then be attacked, and its proteine will yield ammonia, wlich will distil over and may be measured by means of the Nessler tests. For further details of the manner of carrying out work of this description we would refer to the Treatise on Water-analysis, which is now sufficiently well known to chemists.

It was shown some years ago that egg-albumen yields about one tenth of its weight of ammonia when submitted to such a process as the above, and that solutions containing different quantities of egg-albumen yield ammonia exactly proportional in amount to the strength of the solutions of albumen. Our experiments warrant a parallel statement in the case of vegetable proteine; and in the Table about to be given, the ammonia, multiplied by 10, gires a fair approximation to the actual quantity of vegetable proteine in the different samples.

As will be observed, our experiments include many descriptions of wheaten, pea-, rice-, maize-flour, oats, barley, malt, rye, and arrowroot. The last-named is important as showing a very small proportion of proteine.

The pea-flour was ground from the peas in our own laboratory, and passed through a very fine sieve. The rice-flour was likewise of home-manufacture; and the same is true of maize and the malt. The rest were not powdered in the laboratory.

Samples of wheaten flour :- 


\section{Name of sample. Percentage}

1. Cambridgeshire extra-superfine... $1 \cdot 10$

2. Another sample,$\quad \ldots 1 \cdot 00$

3. Household flour, Waterloo Bridge. $1 \cdot 13$

4. Country flour ....................... 1.08

5. Huntingdonshire ................. 1.05

6. Suffolk.............................. $1 \cdot 00$

7. Hungarian ........................... 1 1 10

8. Anotber Hungarian .............. 1.05

$9 . \quad \quad \% \quad \ldots \ldots \ldots \ldots \ldots . . .107$

10. Darblay, Paris ....................... 1.05

11. Vienna.............................. 1.08

12. Australian ......................... 0.92

13. Californian ............................ $1 \cdot 13$

14. American ............................ 1 14

15. Another American ................ 1 1 17

16.

Pea-flour................................. 2*30

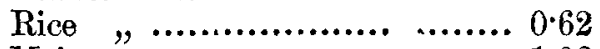

Maize „............................. 1:03

Oats.................................... 1:00

Barley............................... 1 1 10

Malt ................................. $0: 50$

Rye ................................ 1 1.45

Arrowroot ........................ 0.08

In looking through this Table the reader will be struck with the constancy of the quantity of proteine substances in wheaten flour. If one of the American samples (No. 15) be excluded (we believe that there was a little pea-flour in that sample), it will be seen that the highest percentage of ammonia given by any sample of flour is 1.14 ; and excluding the solitary sample of Australian flour, the lowest yield of ammonia is $1 \cdot 00$. Wheaten flour would therefore seem to yield between 1.00 and 1.13 per cent. of its weight of ammonia when subjected to the above process, and, according to the rule above given, would seem to contain from $10^{\circ} 0$ to 11.3 per cent. of proteine compounds.

Maize, oats, and barley, as will be seen, very closely resemble wheaten flour in yield of albuminoid ammonia. Rye, on the other hand, is exceptionally rich in proteine. Apparently it is the most nitrogenous cereal.

The high percentage of ammonia from pea-flour will attract attention; and, applying the rule, pea-flour contains 23.0 per cent. of proteine, which accords with what is known of the pea. The proteine in rice amounts to about half as much as in wheaten flour.

Phil. Mag. S. 5. Vol. 3. No. 19. May 1877. 